\title{
Transnationalism, Social Capital and Gender - Young Pakistani Muslim Women in Bradford, UK
}

\section{Gurchathen Sanghera and Suruchi Thapar-Björkert}

\begin{abstract}
This article considers the relationship between transnationalism and social capital amongst young Pakistani Muslim women in Bradford. Due to their parents’ experience of migration and community-building, and unprecedented advances in modern telecommunications and media, the transnational is omnipresent in the everyday lives of second-generation migrants. We illustrate how they accrue faithbased social capital to negotiate and resist transnationally gendered expectations, norms, values and practices. In particular, in several ways they use faith-based social capital that is transnationally informed: to challenge the patriarchal expectations and norms of their families; to gain access to higher/further education and thereby improve their life opportunities; and to overcome growing anti-Muslim sentiment.
\end{abstract}

Keywords: Bradford, gender, Muslim, social capital, transnationalism

\section{Introduction}

In January 2016, the UK Conservative government announced a new initiative for Muslim women to learn English, so they would become a moderating force and act as vocal opponents of radical Imams in their community. The initiative was seen as a response to concern amongst politicians and policy-makers that young Muslim men become radicalised because of 'the traditional submissiveness of Muslim women', as 
Prime Minister David Cameron put it. ${ }^{1}$ The initiative came under intense criticism from Muslim women's groups, who saw it as reproducing problematic narratives about Muslim women as passive, voiceless victims. They took to Twitter (\#traditionallysubmissive) to highlight their achievements, voice and agency.

This was not the first time that Muslim women became objects of intervention at the behest of UK politicians. For the past decade or so, cultural practices of Muslim women, such as wearing the veil and transnational arranged/forced marriages, have been widely discussed and debated. As Razak (2008: 4) argues, 'while Muslim men have been the target of an intense policing, Muslim women have been singled out as needing protection from their violent and hyper-patriarchal men’. At the same time, the British government has developed a strategy for Muslim women to advise ministers on matters relating to counter-terrorism and radicalization, because they are seen to embody a ‘safer’ and more 'liberal’ Islam (Brown, 2008; AUTHORS, 2012). Indeed, women have been seen as a playing a vital role in the fight against extremism.

The focus of this article is on exploring how young second-generation Pakistani Muslim women accrue faith-based social capital to negotiate transnational gendered expectations, norms, values and practices, whilst resisting growing discrimination and prejudice. The aim is to illustrate how young women are not passive, docile victims of patriarchal expectations and external hostilities; rather, they often confront such challenges by turning to their faith and using it to counter negative stereotypes and discrimination peacefully. At times, this is in sharp contrast to their male counterparts,

\footnotetext{
${ }^{1}$ David Cameron (2016): “More Muslim women should 'learn English’ to help tackle extremism”. The Telegraph, 17 January 2016.
} 
some of whom have decided to tread the fine line between legal/illegal activities and radical Islam (Macey, 1999, 2002). ${ }^{2}$

This article begins with a discussion of social capital and transnationalism, with a particular focus on gender and ethnic/religious forms of social capital. This is followed by a brief overview of Bradford, West Yorkshire, where empirical research was conducted among young Pakistani Muslims. Finally, the paper examines how young Muslim women use faith-based social capital to negotiate transnational expectations and practices. For example, we explore how some young women draw on faith-based social capital in order to progress to higher/further education. Often, Pakistani parents have deep cultural reservations about their daughters attending college or university, particularly as it takes them from under the private surveying gaze of the family. Also, amid growing anti-Muslim sentiment, young Muslim women are turning to faith-based social capital as a means of resistance and resilience.

\section{Gendering Social Capital and Transnationalism}

The concept of 'social capital' has empirical and theoretical utility for understanding how the creation of specific networks and relationships of trust and reciprocity can, inter alia, facilitate upward socio-economic mobility, contribute to community development, increase educational attainment, strengthen democracy and ensure community cohesion (Coleman, 1988, 1990; Bourdieu, 1986; Putnam, 1995, 2001).

\footnotetext{
${ }^{2}$ It is, of course, important to mention that women often take up arms when they face constant threats to their ethnic, religious or political identities. In such cases, it is the threats rather than grievances rooted in gender that are foregrounded (such as women's brigade within ISIS).
} 
Feminists have focused on what a gendered analysis tells us about social capital, and the gender differences in the distribution, nature and mobilization of social capital. First, a gendered analysis of social capital illustrates how it is 'imbued with gender inequalities and gendered hierarchies' (Van Staveren, 2002: 22) which can potentially affect the accumulation and investment of social capital. Thus gender inequality can often translate into inequality in social capital and human capital that may contribute to existing social and economic inequalities. Second, there are significant differences in the social networks and embedded resources between women and men. Women's networks are smaller, informal, more homogeneous (in respect of sex, age, education and income), and larger in terms of kin, and they belong to expressive or community based organisations. Generally men’s organisational experiences tend to be economic or recreational (Gidengil and O’Neill, 2006: 5, 264; Foley and Edwards, 1999: 146;; Lowndes 2006: 234; Moore, 1990: 727; Morrow, 2006). Third, the private sphere as a site for building social capital is neglected; and traditional institutions such as 'the family’ are treated normatively, even though they are frequently sites of power and contestation (Gidengil and O’Neill, 2006; Lowndes, 2006; Morrow, 1999, 2001, 2006). This can be attributed to the continued relevance of the public/private divide, which underestimates the relevance of the domestic economy for community development.

Yet we would argue that it is problematic to assume that women's social capital is less significant because of the structural disadvantages that they often encounter, relative to men. Often, women build and mobilise stocks of social capital away from the conventional gaze of the theorists, particularly within the home and local (ethnic and religious) community (Stolle and Micheletti, 2006; AUTHORS, 2010). Relatedly, 
it would be incorrect to assume that all women have access to the same kind of social capital, as it is likely to be influenced by the intersectional axes of class, generation, race/ethnicity and religion.

A largely US-based literature explores how various ethnic groups mobilise collective resources (family, kinship and community) to overcome particular disadvantages (e.g. Portes and Zhou, 1993; Zhou, 1992). Bankston and Zhou (2002: 286) examine 'ethnicity as a resource' and define social capital 'to not only include the resources held by individuals or groups but also as "processes” of social interaction leading to constructive outcomes'. ${ }^{3}$ The relationship between families and the community (local and transnational) is understood to be cyclical. The community is an important vehicle for reinforcing various norms, beliefs and values (e.g. education and hard work) transmitted by the family, and vice versa.

Others have examined the role of religion or faith-based social capital, particularly in terms of how it can accrue physical resources and social networks (Furbey et al., 2006; Smidt, 2003). Religious-based social capital has also been viewed suspiciously. Hopkins (2011: 530) warns that '[a]n unfortunate impediment to analysing faith identities and how they contribute to the production of social capital is a tendency to regard religion as irrational and as therefore inherently problematic’ - especially Islam and Muslims.

\footnotetext{
${ }^{3}$ For example, overcoming limited human and economic capital among first-generation Vietnamese immigrants in the US is explained by the social capital of their 'intact families' (Bankston and Zhou, 2002).
} 
Social capital has also been used to explore contemporary processes of transnationalism, for example the emergence of transnational families that have been understood discursively, such as in a sense of de-territorialised solidarity between a group of strangers of 'imagined communities’ (Anderson, 1983), or materially, whereby goods, funds and opportunities flow in and through transnational circuits (Kivisto, 2001). Contrary to the argument that mobility will deplete conventional stocks of social capital (Coleman, 1988), new forms of social capital are reestablished (Ballard, 2003; Goulbourne, 2002; Portes et al., 1999; Vertovec, 2001). Resources are mobilised through social networks to facilitate and sustain family relationships across national borders (Glick Schiller et al., 1992; Goulbourne and Chamberlain, 2001; Portes et al., 1999; Zontini, 2010). Social capital is pivotal in the decision to migrate, to facilitate settlement and the acquisition of information and resources in the new country, and can be readily mobilised within transnational family networks in times of need, for instance economic hardship (Ballard, 2003; VoigtGraf, 2004). Whilst immigrants are not tied to localised communities, kin and ethnic ties bound up in notions of trust, reciprocity and solidarity continue to play a central role in processes of migration and settlement. Landolt (2001: 217) describes how norms and practices come to exist through 'circuits of transnational obligations and interests'. ${ }^{4}$ Often transnational marriage plays a key role in the processes described by Landolt (2001) and Vertovec (2004), especially in extending a family’s kinship network and collective upward mobility.

\footnotetext{
${ }^{4}$ Similarly, Vertovec (2004: 17) highlights how: “[f]or many individuals, families and communities in both sending and receiving contexts, transnational patterns of everyday activity, communication and exchange become embedded in a kind of transnational moral economy of kin.”
} 
In summary, people's family lives increasingly transcend the nation state and involve the expectations and concerns of people living many miles away. Advancements in communications and technology, and their relative affordability, have meant that the world 'out there' and the 'homeland' (e.g. kin, faith/religion and ethnicity networks) are closer than ever before for transnational families. People’s everyday lives are conditioned in terms of expectations (e.g. work, education, marriage and life course), moral economy of kin (e.g. providing support and guidance to kin based on trust and reciprocity), and institutional structures (e.g. how to organise or participate in religious/ethnic community and local association). Significantly, it has meant that kinbased networks, relationships of trust and reciprocity are more easily sustained across space, while gendered, religious and cultural expectations, norms, values and practices are transmitted inter-generationally.

\section{Bradford}

This article draws on empirical data collected in the city of Bradford, West Yorkshire, UK, where a number of national and international controversies have resulted in the increasing visibility of the Pakistani Muslim community. These include: the rise of right-wing politics during the 1970s and 1980s; the Honeyford affair (1980s) concerning the perceived racist remarks by a head teacher on the lack of social integration and an adherence to cultural, religious and ethnic identities amongst local Pakistanis; and publication of Salman Rushdie’s book, Satanic Verses, in 1998. The reaction of the Muslim community to the perceived blasphemous portrayal of revered Islamic figures started in Bradford, as were the urban disturbances of 1995 and 2001 when, for the first time, the protagonists were predominantly young Pakistani Muslim 
men (Burlet and Reid, 1998; Macey, 2002, 1999). Young women, for the most part, were not directly involved in these disturbances.

We draw on in-depth interviews with young Pakistani Muslim men and women, conducted by the first author in four predominantly Pakistani Muslim neighbourhoods in Bradford's inner city (Manningham, Girlington, Heaton-Oak Lane, and West Bowling) (McLoughlin, 2006). During July 2004 and May 2005, a total of 54 interviews were conducted: 29 female, 25 male. The British-born respondents were aged between 16 and 20 years of age and were recruited from schools, youth clubs, the university and colleges. All the interviews were recorded, transcribed, coded and analysed using Atlas-ti software, in a grounded theory approach. We used pseudonyms to protect the anonymity of our respondents (for an in-depth methodological discussion, see AUTHORS, 2008). In this article, we only focus on women as our data supports and builds on growing body of literature that illustrates how Muslim immigrant women are exercising agency through reclaiming their religious traditions through embodied and knowledge-based piety (Amir-Moazami and Salvatore, 2003; Jouili and Amir-Moazami, 2006).

\section{Young Women - Change and Resistance}

The young women in our research talked about how the migratory and transnational experiences and practices of their parents informed their relationships with them, with their family in Pakistan, and with the larger society. ${ }^{5}$ Parents often relied upon narratives of their 'loss', ‘sacrifice' and 'hardship' when they arrived in the UK in

\footnotetext{
${ }^{5}$ According to Yeoh et al. (2005: 308): “[t]he transnational family as a formation derives its lived reality not only from material bonds of collective welfare among physically dispersed members but also a shared imaginary of 'belonging', which transcends particular periods and places to encompass past trajectories and future continuities.”
} 
order to instil particular norms and values in young people (e.g. the need to respect their elders, and arranged marriage to first cousins). This explained how and why gendered expectations were often reproduced inter-generationally. Young women were expected to take on the traditional role as a dutiful wife, daughter-in-law and mother. Family honour (izzat), which is closely tied to patrilineal decent group (biraderi), remained a central tenet of transnational families. Young women, in particular, were expected to respect and adhere to it. Failure to do so often resulted in being shunned by the family and community, forced into an arranged marriage or, in some extreme cases, subjected to violence and even murder (i.e. honour-basedviolence) (Werbner, 2007; Meetoo and Mirza, 2007). ${ }^{6}$

Our research found that young women demonstrated agency via a religious rather than ethnic identity because they saw religion to be more empowering than their culture and cultural identity. Rather than being a source of oppression and exclusion (Hopkins, 2011), religion for these women was a resource to be mobilised against what Ali (1992: 115) describes as a ‘northern conservatism’ in northern English cities, where an overbearing Pakistani patriarchal masculine culture suppresses Pakistani women. Unlike some of their male counterparts who were associated with deviant masculinities, the disturbances, 'gang culture', underachievement (e.g. education and economic) (Macey, 1999, 2002), young women used their faith identity to negotiate, challenge and transform transnational gendered norms and expectations, on the one hand and, on the other, to counter growing anti-Muslim hostility. Indeed, 'religious

\footnotetext{
${ }^{6}$ Recently, Naz Shah (2016), Minister of Parliament for Bradford West, which includes Manningham, reiterated, 'we do have patriarchal pockets in our communities which won't and don't support women going out and being confident and partaking in civil society because they want that patriarchal structure to continue'. The Guardian, 18 January 2016.
} 
cultural capital’ (Ramji, 2007: 1181) became an important tool for personal betterment, particularly through education, for many young Muslim women.

The respondents built this religious capital with like-minded women (and men) whom they met at Islamic conferences, book readings, prayer sessions or school/college/university. For many of the young women, such networks and associations constituted a religious community that provided 'safe spaces' where they could share their ideas and learn more about their faith. Indeed, it was an outlet where they could air their frustrations and seek solace. Often such interactions took place at university or college and in Muslim associations. The respondents also arranged Qur'an reading sessions and social evenings where they would discuss their faith in greater detail. They also discussed more contentious issues such as the media and political demonization of Islam, and how they ought to respond to this as individuals. Many held the view that they each had a responsibility not to besmirch Islam through their daily interactions with non-Muslims, even in the face of growing hostility.

Transnational linkages were also established via particular chat-rooms on the Internet and/or sharing their ideas about their personal faith journey with Islamic bloggers. This community was seen to be more progressive and valuable in, for example, emphasising the Islamic perspective about the importance of education as a counter to ignorance. It was both a source of inspiration and support for many of the young women in negotiating and challenging transnational cultural practices whilst bringing about positive change in Bradford. 
Thus, women drew on religion to develop strategies to challenge their families’ cultural expectations and practices. Central to the women's strategy was the decoupling of faith from cultural beliefs and practices. These women were often critical of the fact that their parents had a limited or very literal understanding of the Islam, and were therefore ignorant about how, for example, certain traditional cultural practices were understood to be religiously upheld, even though the two may have opposing perspectives or no position on the matter whatsoever. An example was higher or further education and careers for women. Many young women reiterated the value of education from a religious perspective. For example, one female respondent, Sara (aged 17), talked about how education and educating oneself is absolutely central to Islam:

$$
\begin{aligned}
& \text { What I have learnt from my religion is that you need to educate } \\
& \text { yourself if you want to achieve anything. What I found is that people } \\
& \text { who are more religious have gone further in education so there is a } \\
& \text { kind of correlation between people's religious kind of spirituality } \\
& \text { and their achievement. }{ }^{7}
\end{aligned}
$$

Often, gaining access to higher/further education entailed building relationships of trust with parents. Young women were critical of how their parents still held onto gendered expectations about female education that were no longer relevant in Pakistan. Indeed, there was a sense that their parents were out of touch with the changes that had taken place in Pakistan and they were holding onto an image that no longer existed. They were also critical of how their parents' judgement was always informed by worst-case scenarios (e.g. that the daughter would elope or be enticed

\footnotetext{
${ }^{7}$ Interview conducted on July 20, 2004.
} 
into Western ways such as drinking and smoking, and bring shame and dishonour to the family). Indeed, whilst many parents appreciated the importance of education, they often opposed the values that education promoted, such as individuality, freedom, and greater autonomy. A number of female respondents spoke anecdotally about female friends being removed by their parents from compulsory education just before they were about to sit for their final exams and taken back to Pakistan to be married. In some instances, this went against the key goal of transnational family strategy to enhance ‘social, cultural and symbolic capital’ through education (Waters, 2005; Yeoh et al., 2005: 312).

One way in which some of the women sought to build this trust was by demonstrating and performing their religion more obviously, for example wearing the hijab (headscarf), which then counterpoised them with their supposedly less religious, nonhijab wearing female counterparts, who were looked upon with greater suspicion by parents when out in public away from the scrutiny of their family. Similarly, Ali (1992: 114) comments that 'the good Muslim girl who shows unusual devotion to her faith may find it possible to express a desire for higher education or professional employment without risking her position'. Sara, the respondent whom we mentioned earlier, was considered very religious by her parents because she wore the hijab, prayed five times a day and was planning a pilgrimage to Mecca. In discussing how cultural practices within the community can be barriers to women's educational aspirations, Sara said: 
I think that as long as it is Islamically okay to do a certain thing, even if the whole community was against it, I will do it because the community is not always right. ${ }^{8}$

Sara’s close friend, Laila (aged 17), spoke about the importance of faith and education, and the cultural burdens of patriarchy:

Learning that knowledge is light [...] comes from faith. I would like to clarify that in terms of an Islamic point of view, you get a country like Afghanistan where women are not being educated which is not Islamic at all. I would class [i.e. categorise] that and see that as patriarchy and that it is totally cultural. ${ }^{9}$

Faith-based social capital also served another purpose. In the face of growing antiMuslim sentiment, the young women relied on their faith-based networks for support. The fear of anti-Muslim reprisals after 9/11 had deep reverberations within Muslim communities. For instance, Nabila (aged 17) talked about the growing hostility towards Muslims since 9/11 and her frustration in challenging it:

It's giving them [Muslims] a bad name case even if he [Osama Bin Laden and al-Qaeda] for the good or something, he's done it for the worse because it's gone off [backfired] on us and not him. I didn't

\footnotetext{
${ }^{8}$ Interview conducted on July 20, 2004.

${ }^{9}$ Interview conducted on August 6, 2005.
} 
tell him to go and do it [attack the Twin towers in New York], it's not my fault I'm Muslim, it's just him and his own fault. ${ }^{10}$

A common theme that we encountered during the research was the question of whether women should wear the hijab, particularly as it made it easier for the women to be singled out as Muslim and thus a target of discrimination and prejudice. For example, Sara said:

I think it's [hostility towards Muslims] getting worse... because of the media... and you have got the BNP [far-right British National Party] kicking in as well... now my clothing [referring to her hijab] ...I get asked questions and funny looks that maybe I wouldn't have got three or five years back... things are not working for Muslims in the media and in politics... now it's heightened [hostility towards Muslims], it's working more against Muslims. ${ }^{11}$

In discussing how Islam influences her life and the significance of wearing a hijab, Iffat (age 19) stated that 'it's like identification, that, “Ok, I’m Muslim” - you feel protected'. Many of the women gained support from their networks when they encountered hostility for wearing the hijab or for being Muslim. For example, Anika (aged 18) discussed how:

For me and my friends wearing the hijab means that we identify with each other... we're sisters and support one another... when you face trouble, you know, like racism, abuse, being called names... Just being with likeminded

\footnotetext{
${ }^{10}$ Interview conducted on September 7, 2005.

${ }^{11}$ Interview conducted on September 8, 2005.
} 
people, people who understand and share what you believe in [i.e. faith] and experience helps lots. ${ }^{12}$

Indeed, it was often because of this support network that women were able to encourage other women who were unsure about the responses that they may encounter when they decided to wear the hijab. But wearing the hijab also marked people as different, as 'Outsiders', and with suspicion. In recalling a trip to Italy in 2004, Iffat (age 19) discussed how ‘times have changed' and that Muslims and Islam have become 'public enemy number one'. Iffat and her sister were stopped by policemen because as she says,

I was wearing a headscarf and they asked, 'Where are your documents?' They just said it to me, not my sister because she doesn't wear a scarf, so I was like, 'We're British, we're from Britain', he then just shut up and walked off. ${ }^{13}$

In this case, Iffat was aware of the potential problems associated with her faith identity and instead chose to foreground her national identity. Parents were often less religious than their daughters and had reservations about their wearing the hijab:

My mother because of all this terrorism she was watching on the news, she said, 'Iffat I fear for your life so take it off'...and my father would say, 'Oh there's no need to wear it, it's ok you know. ${ }^{14}$

\footnotetext{
${ }^{12}$ Interview conducted on August 16, 2005.

${ }^{13}$ Interview conducted on October 5, 2005.

${ }^{14}$ Interview conducted on October 7, 2005.
} 
Despite these concerns, many young women decided to keep wearing the hijab. Indeed, the strength and resilience to continue wearing the hijab came from the women who were also wearing one.

\section{Conclusion}

Transnationalism alerts us to the fact the lives of migrants are not tied to any one nation-state. Rather people have multiple layered affinities and identities - to places, spaces, peoples, cultures, religions, and traditions near and afar. Such transnational relationships have become increasingly problematized recently. Concerns with the supposed helplessness and lack of agency of Pakistani women in the face of an overly burdensome transnational patriarchal culture has become a key focus in political and policy circles in the UK, particularly in terms of how it links with the securitisation (i.e. anti-terror) agenda. This article problematises these stereotypes by examining the ways in which young women navigate their everyday transnational lives in Bradford. Whilst young women are expected to adhere to transnational patriarchal expectations, values and practices, women resist by developing coping strategies that centre on faith-based social capital - faith is a resource. They understand 'being Muslim' as a source of strength, solace, and security in terms of negotiating (albeit subtly), on the one hand, relations and structures of power within their own communities and, on the other hand, increasing discrimination and hostility externally.

Overall, we illustrate how unequal gendered power relations do not undermine the capacity to build social capital - including faith-based capital. Instead, we have argued that faith based capital is mobilized by women to: negotiate both the public and the private; advance educationally; and challenge the misconceptions of the 
supposed incompatibility between gender equality and Islam. Despite experiencing 'northern conservatism' and patriarchy within predominantly the private sphere and Islamophobia in the public sphere, young women mobilized faith-based capital to negotiate these obstacles.

\section{References}

Ali, Y. (1992). "Muslim women and the politics of ethnicity and culture in northern England”. In: G. Sahgal and N. Yuval-Davis (eds.) Refusing Holy Orders: Women and Fundamentalism in Britain (pp. 101-123). London: Virago.

Amir-Moazami, S. and Salvatore, A. (2003). "Gender, Generation, and the Reform of Tradition: From Muslim Majority Societies to Western Europe”. In: S. Allievi and J. Nielsen (eds.) Muslim Networks and Transnational Communities In and Across Western Europe (pp. 52-78). Leiden: Brill.

Anderson, B. (1983). Imagined Communities: Reflections on the Origin and Spread of Nationalism. London: Verso.

Ballard, R. (2003). “The South Asian Presence in Britain and Its Transnational Connections”. In: H. Singh, B. Parekh and S. Vertovec (eds.) Culture and Economy in the Indian Diaspora (pp. 197-223). London: Routledge.

Bankston, C. and Zhou, M. (2002). "Social capital as process: The meaning and problems of a theoretical metaphor”. Sociological Inquiry, 72 (2): 285-317.

Bourdieu, P. (1986). “The forms of capital”. In: J. Richardson (ed.) Handbook of Theory and Research for the Sociology of Education (pp. 241-258). New York: Greenwood. 
Brown, K. (2008). “The promise and perils of women’s participation in UK mosques: The impact of securitization agendas on identity, gender and community”. British Journal of Politics and International Relations, 10: 472-491.

Burlet, S. and Reid, H. (1998). “A gendered uprising: political representations and minority ethnic communities”. Ethnic and Racial Studies, 21 (2): 270-287.

Cameron, D. (2016). “More Muslim women should ‘learn English’ to help tackle extremism”. The Telegraph, 17 January 2016.

Http://www.telegraph.co.uk/news/uknews/terrorism-in-theuk/12104556/David-Cameron-More-Muslim-women-should-learn-English-tohelp-tackle-extremism.html (retrieved 22 February 2016).

Coleman, J. S. (1988). “Social capital in the creation of human capital”. American Journal of Sociology, 94: 95-120.

Coleman, J. S. (1990). Foundations of Social Theory. Harvard: Harvard University Press.

Foley, M. W. and Edwards, B. (1999). “Is it time to disinvest in social capital?”. Journal of Public Policy, 19: 141-173.

Furbey, R., Dinham, A., Farnell, R., Finneron, D., Wilkinson, G., Howarth, C., Hussain, D. and Palmer, S. (2006). Faith as Social Capital. London: Joseph Rowntree Trust.

Gidengil, E. and O’Neill, B. (2006). “Removing rose-colored glasses: Examining theories of social capital through a gendered lens”. In: B. O’Neill and E. Gidengil (eds.) Gender and Social Capital (pp. 1-15). London: Routledge.

Glick Schiller, N., Basch, L. and Blanc-Szanton, C. (eds.) (1992). Towards a Transnational Perspective on Migration. New York: New York Academy of Sciences. 
Goulbourne, H. and Chamberlain, M. (eds.) (2001). Caribbean Families in Britain and the Trans-Atlantic World. Basingstoke: Macmillan Caribbean.

Goulbourne, H. (2002). Caribbean Transnational Experience. London: Pluto Press.

Hopkins, N. (2011). “Religion and social capital: Identity matters”. Journal of Community and Applied Social Psychology, 21: 528-540.

Jouili, J. S. and Amir-Moazami, S. (2006). “Knowledge, Empowerment and Religious Authority among Pious Muslim Women in France and Germany”. The Muslim World, 96 (4): 617-642.

Kivisto, P. (2001). “Theorizing transnational immigration: A critical review of current effort”. Ethnic and Racial Studies, 24 (4): 549-577.

Landolt, P. (2001). 'Salvadoran economic transnationalism: Embedded strategies for household maintenance, immigrant incorporation, and entrepreneurial expansion”. Global Networks, 1 (3): 217-241.

Lowndes, V. (2006). “It’s not what you've got, but what you do with it: Women, social capital, and political participation”. In: B. O’Neill and E. Gidengil (eds.) Gender and Social Capital (pp. 213-241). London: Routledge.

Macey, M. (1999). “Class, gender and religious influences in changing patterns of Pakistani Muslim violence in Bradford”. Ethnic and Racial Studies, 22 (5): 845-866.

Macey, M. (2002). “Interpreting Islam: Young Muslim men’s involvement in criminal activity in Bradford”. In: B. Spalek (ed.) Islam, Crime and Criminal Justice (pp. 19-49). Cullompton, UK: Willan.

McLoughlin, S. (2006). "Writing a British-Asian city: Race, culture and religion in account of postcolonial Bradford”. In: S. Sayyid, N. Ali and V. S. Kalra (eds.) A Postcolonial People: South Asians in Britain (pp. 110-149). London: Hurst. 
Meetoo, V. and Mirza, H S. (2007). “There is nothing 'honourable' about honour killings: Gender, violence and the limits of multiculturalism”. Women's Studies International Forum, 30 (3): 187-200.

Moore, G. (1990). “Structural Determinants of Men’s and Women’s Personal Networks”. American Sociological Review, 55 (5): 736-735.

Morrow, V. (1999). “Conceptualising social capital in relation to the well-being of children and young people: A critical review”. Sociological Review, 47: $744-765$.

Morrow, V. (2001). “Young people’s explanations and experiences of social exclusion: Retrieving Bourdieu’s concept of social capital”. International Journal of Sociology and Social Policy, 21 (4-6): 37-63.

Morrow, V. (2006). “Conceptualizing social capital in relation to children and young people: Is it different for girls?” In: B. O’Neill and E. Gidengil (eds.) Gender and Social Capital (pp. 127-151). London: Routledge.

Portes, A., Guarnizo, L. and Landolt, P. (1999). “The study of transnationalism: Pitfalls and promise of an emergent research field”. Ethnic and Racial Studies, 22 (2): 217-237.

Portes, A. and Zhou, M. (1993). “The second generation: Segmented assimilation and its variants among post-1965 immigrant youth”. Annuals of the American Academy of Political and Social Science, 530: 74-98.

Putnam, D. R. (1995). “Bowling alone: America’s declining social capital”. Journal of Democracy, 6 (1): 65-78.

Putnam, D. R. (2001). Bowling Alone: The Collapse and Revival of American Community. New York: Simon and Schuster. 
Ramji, H. (2007). “Dynamics of religion and gender amongst young British Muslims”. Sociology, 41 (6): 1171-1189.

Razak, S. (2008). Casting Out: The Eviction of Muslims from Western Law and Politics. Toronto: Toronto University Press.

Shah, N. (2016). “Bradford's language bubbles: 'it’s perfectly possible never to speak English””. The Guardian, 18 January 2016. Http://www.theguardian.com/uknews/2016/jan/18/bradford-language-bubbles-never-speak-english (retrieved 22 February 2016).

Smidt, C. (2003). “Introduction”. In: C. Smidt (ed.) Religion as Social Capital Producing a Common Good (pp. 1-18). Waco TX: Baylor University Press.

Stolle, D. and Micheletti, M. (2006). “The gender gap reversed: Political consumerism as a women-friendly form for civic and political engagement”. In: B. O’Neill and E. Gidengil (eds.) Gender and Social Capital (pp. 45-73). London: Routledge.

Van Staveren, I. (2002). Social Capital: What is in it for Feminist Economics? The Hague: Institute of Social Studies.

Vertovec, S. (2001). “Transnationalism and identity”. Journal of Ethnic and Migration Studies, 27 (4): 573-582.

Vertovec, S. (2004). Trends and Impacts of Migrant Transnationalism. Oxford: Centre on Migration, Policy and Society Working Paper No. 3, University of Oxford.

Voigt-Graf, C. (2004). “Towards a geography of transnational spaces: Indian transnational communities in Australia”. Global Networks, 4 (1): 25-49.

Waters, J. (2005). “Transnational family strategies and education in the contemporary Chinese diaspora”. Global Networks, 5 (4): 359-378. 
Werbner, P. (2007). "Veiled Interventions in Pure Space. Honour, Shame and Embodied Struggles among Muslims in Britain and France”. Theory, Culture and Society, 24 (2), 161-186.

Yeoh, S., Huang, S. and Lan, T. (2005). “Transnationalizing the ‘Asian’ family: imaginaries, intimacies and strategic intent”. Global Networks, 5 (4): $307-315$.

Zhou, M. (1992). Chinatown: The Socioeconomic Potential for an Urban Enclave. Philadelphia, PA: Temple University Press.

Zontini, E. (2010). "Enabling and constraining aspects of social capital in migrant families: ethnicity, gender and generation”. Ethnic and Racial Studies, 33 (5): 816-831. 